\title{
Social Democracy in a Postcolonial Island State: Dom Mintoff's Impact
}

\author{
Peter Mayo \\ This is an accepted manuscript of an article published by Taylor \& Francis in \\ Socialism and Democracy online 17 April 2013, available \\ online: http:/ / www.tandfonline.com/ loi/ csad20 DOI:10.1080/08854300.2012.759743
}

To link to this article: http:/ / dx.doi.org/ 10.1080/ 08854300.2012.759743

The Mediterranean small island state of Malta (population 400,000) recently paid final respects to its internationally best known politician, former socialist Prime Minister Dom Mintoff, who died at his residence on August 202012 at the age of 96. Together with other figures such as Michael Manley of Jamaica, Kwame Nkrumah of Ghana, Maurice Bishop of Grenada and Julius K. Nyerere of Tanzania, Mintoff can be regarded as one of the classic postcolonial leaders. He had his shortcomings, notably that of having allowed room for thugs to perpetrate political violence, which tarnished his party's image, and engaging in the dangerous game of playing off one cold-war bloc against the other, in a bid to attract the attention of superpowers. He would befriend Willy Brandt and Aldo Moro, key and influential figures in German and Italian politics, just as he would establish relations with Chou en-Lai of China, Colonel Gaddafi of Libya (and his Prime Minister, Abdussalam Jalloud), and Kim il Sung of North Korea. He would employ or condone strong-arm tactics in response to what he regarded as attempts by different sectors of the Maltese establishment to sabotage his government's efforts at social and political change. These tactics were employed with greater intensity in the years leading up to and following the 1981 General Elections which yielded a 'perverse' result, his party obtaining the majority of seats despite garnering fewer votes than the opposition Nationalist Party.

On the other hand, his name is revered by those who saw in him the catalyst for belated social change in an island with archaic structures and priest-ridden politics. They highlight his notable achievements in social, economic and foreign policies. These include: the substantial reduction of material poverty (I recall beggary being a feature of 
Maltese streets that was all but eliminated with Mintoff's first electoral victory after the country's 1964 independence from Britain, which led to sixteen uninterrupted years of Labour rule); the creation of a welfare state that included an increase in pensions, the introduction of salary bonuses, and a children's allowance; the establishment of a minimum wage; the development of a much criticised and derided military corps which eventually led those who joined into secure jobs; the creation of state-financed companies in a variety of areas including international transport (e.g. the national carrier Air Malta); the imposition of protective tariffs - in the face of considerable criticism - in order to encourage domestic production; a bold effort to convert what was hitherto a 'fortress economy,' centering around the British garrison's needs, into a non-mercantile but industrial capitalism fuelled by local and foreign capital; a broad programme of social housing; the affirmation of a strong national identity through national monetary, banking, international transport and telecommunications systems; an opening towards the Arab world (Sammut, 1989), ${ }^{\mathrm{i}}$ albeit dominated by relations with neighbouring Libya led by Gaddafi; efforts to drum up support for and an understanding of the Palestinian cause, allowing the opening, in the mid '70s, of a PLO office in Malta; his Tito-inspired faith in self-management with its introduction at the Malta Drydocks, Melita Knitwear and Cargo \& Handling companies; his government's efforts at introducing worker representatives on companies' boards of directors most notably in state-owned companies including banks; his faith in cooperatives which he reiterated even in his life's latter stages (in a 'face to face' meeting I held with him at his residence in 2009); and of course his belief in and efforts towards a nuclear-free Mediterranean region which led to his government pursuing a politics of non-alignment, in the tradition of Tito, Makarios, and Nehru.

As far as education is concerned, he will always be criticised by certain sectors of Maltese society for the 'reform' his government introduced in the late '70s in the Higher Education sector (Mizzi 1995; Baldacchino 1999); more than a reform, it involved a radical overhaul of the entire system (Mayo 2012b). The faculties of Arts, Science and Theology were abolished (Austin 1978) to make way for 'functional' courses deemed necessary for the development of an industrialized economy. This made the university less of an appendage to the established traditional professions (the aspect criticised by German sociologist Ralph Dahrendorf, whom Mintoff had brought in as an adviser on 
Higher Education, but who subsequently criticised the changes introduced by the Mintoff government - Schembri 1982).

Mintoff's government was also criticised for the introduction of what many consider to have been a sudden and ill-prepared comprehensive system of schooling (Borg \& Mayo 2005). It was limited to the public sector (Zammit Marmara`, 2012), while its coexistence with a selective private (mainly church-run) system led to the transfer of certain pupils by their parents to this sector. But the Mintoff government is to be credited with notable achievements also in the general education system. The attempt at introducing comprehensives was part of an overall effort to reduce elitism in education. The government's eventual U turn, however, with the new emphasis on a very competitive meritocratic system of entry to the reintroduced (in 1981) state grammar schools and university, demonstrated little cognizance of sociological research indicating the middle-class bias of any form of selectivity. Among the achievements in the education sector were: the establishing of kindergartens; the attempt to reform and render free the church schools, which alas led to violence by demonstrating dockworkers against the Archbishop's Curia; the contributions of Labour governments of the ' $50 \mathrm{~s}$ and ' 70 s to the development of technical and vocational education (Sultana 1992) - albeit criticised in the ' 70 s for creating further segmentation in the educational system; the introduction of a salary scheme for students in the state sixth forms and university through the pupilworker and worker-student schemes often smacking of Chinese and other socialist influences (Mao's work-study periods; Marx's notion of 'polytechnical education') (Livingstone 1984) but, according to a parliamentary statement by Mintoff himself, actually inspired by the North American cooperative university model (Schembri 1982, 42; Spiteri Campbell 1984, 11 ).

At a more general level, Mintoff engaged in a lifelong attempt to confront the country's social establishment comprising local elites, including ecclesiastical authorities in a predominantly Catholic country, civil service administrators, traditional professional lobbies, and a class of importers (the latter being representatives of merchant capital). $\mathrm{He}$ saw them as bulwarks of the archaic system his party wanted to overhaul in a bid to modernise the country - as important elements of the kind of pre-industrial society analysed by Gramsci in his notes on the 'Southern Question.' 
Other achievements of the Mintoff government include the introduction of equal pay for men and women (1974), the decriminalisation of homosexuality, the removal of the death penalty and, most importantly, the introduction of a national health service, provided to the different localities throughout the country via the setting up of polyclinics. The list cannot be exhausted.

Mintoff always presented himself as a socialist through and through. He even spoke of the need to foster "a socialist generation" (Briguglio 2001, 67). He never shied away from using the term 'socialism' (MLP 1976) even if his economic policy reflected a notable and accelerated attempt at introducing what he must have perceived to be a belated process of industrial capitalist development - export-oriented and guided by foreign investment (Vella 2009). I would argue that, given the pragmatist nature of the brand of socialism espoused by Mintoff (Sant 2004), the attempt was at developing a mixed economy, in which a socialist politics was to rest on a strong industrial economic base, perhaps inspired by the Scandinavian model. Mintoff was to write in his later years, ...when, in 1979, the democratic socialist government freed Malta from the foreign military powers, it did not have a class of entrepreneurs and financial investors comparable to those in ...western democratic powers that ruled it.

To make good for this deficiency, the socialist government could not, neither did it wish to have recourse to the Marxist system. It resorted instead to profit making incentives to enable private enterprise share the burden for a speedy industrialisation and the simultaneous building of Malta's economic infrastructure - airport, seaports, shipbuilding and ship repair facilities, granaries, roads structure, tourism facilities, breakwaters and their ancillary facilities. ${ }^{\text {ii }}$

He twice travelled to Britain to persuade industrialists to invest capital in Malta (BBC News 2012). His second meeting with the Confederation of British Industrialists took place on December 81977 (see Muscat, 2007). ${ }^{\text {iii }}$

With regard to the Labour government's attempt at modernising the country, one ought to underline an apparent contradiction attributed to Mintoff: he conveyed the impression that he mistrusted modern technology, perhaps fearing its potentially negative effect on the number of jobs made available. It is the sort of distrust we also discover in Tanzanian President Julius Nyerere, even though the two contexts were markedly different. Once again, the pragmatic nature of the kind of socialism embraced by the 
Malta Labour Party (Sant 2004) should be borne in mind. The party drew inspiration from both the European socialist tradition and that prevalent in the 'Third World' given, in the latter case, the country's postcolonial condition. On the eve of the 1987 General Elections, a section of the international press branded Mintoff's politics, faithfully followed by his successor, Karmenu Mifsud Bonnici, 'Third World oriented' in contrast to the purportedly more 'Westernised' politics of the opposing Nationalist Party which won the contest. This type of branding strikes me as reductionist.

Ever so ready to take on the 'establishment', Mintoff never compromised his principles simply to win elections. His party's programme for social reform, including the introduction of civil marriage, and separation of church and state, provoked the Church's wrath in the ' 60 s and specifically the wrath of ultra-conservative Archbishop Sir Michael Gonzi, who was not enthusiastic about Pope John XXIII's Vatican Council II and its outcomes. This was the same archbishop who campaigned against and undermined the integration attempt, which would have enabled the Maltese working class to benefit from the same level of social services and standard of living of the country's colonizer (once that opportunity was lost, Mintoff switched to his Plan B, that of self-determination). The Archbishop was dead set against Mintoff's social reform programme, viewed by many as a process of modernization that threatened the entrenched interests of the ruling establishment. Archbishop Gonzi thundered an interdiction, which cost Labour two general elections. Supporters of Labour who died during the period were denied a burial in consecrated land. They would have been allowed to marry only inside the sacristy and not the church... and so forth. No political compromises were made by Mintoff and his party (Fenech 2012). Labour's mass and street corner meetings were interrupted by the pealing of church bells. Short term interests were sacrificed for long term gains. Mintoff could easily have caved in by not insisting on the measures a prospective Labour government intended to introduce. In doing so he might well have won the two elections in question. He and his colleagues however stuck to their principles and this cost them dearly at the polls. I wonder if parties who, nowadays, shy away from tackling head on the immigration and racism issues for fear of losing precious electoral votes, should take a leaf out of their book and adopt a principled stance on the matter. For certain sectors of 
the electorate, the question of inter-racial solidarity seems to be anathema just as the proposed measures, concerning Church -state relations, were in the 60's.

Dom Mintoff placed Malta on the map. Love him or hate him, one would be hardpressed to deny this. In my estimation, Mintoff is one of the very few Maltese political figures worth writing about for an international readership. An avid sportsman (he swam almost daily), which on paper satisfied one of the requirements for the then maleexclusive Rhodes scholarship, he was known for his iron-fisted control, 'hair dryer treatment' rants, and reluctance to suffer fools gladly. Mintoff avoided pomp. He certainly turned down proposals for an Honoris Causa being planned for him by the University of Malta, though he accepted the one provided, in the mid-'70s, by the University of Athens, perhaps out of national interest or in view of its keeping with his vision of a Mediterranean politics, centering around the idea of a nuclear free basin. He was to write, in his later years, that of all the academic qualifications he possessed, this is the one which granted him the greatest satisfaction since it was born out of recognition of “my small country's great contribution to the Mother of Western Democracies to regain her freedom from a dictatorship of colonialists, sponsored and financed by the C.I.A. of the U.S.A." iv Mintoff's government and party also assisted with the plight of Palestinians and Algerians in their respective struggles for self-determination, also helping, in the former case, with the education of some of their youth in Malta. ${ }^{\mathrm{v}}$

His followers take pride in reminding one of Lord Carrington's statement on Michael Parkinson's popular BBC talk show, namely that Maltese Prime Minister Dom Mintoff was the toughest negotiator he ever came across. Carrington was referring to the agreement Mintoff renegotiated with him, as British Defence Secretary, in 1972, with regard to the lease of the island to accommodate the British Mediterranean military base. Mintoff secured one large final financial package trebling the sum from the original 5 million sterling per annum to 14 million. In thus making the British pay up in what was to be their final lease of the facilities (also tied to certain conditions, including that there was to be no use of the bases for attacks against Arab countries), Mintoff laid the foundation for the eventual evacuation of the island by British forces. He obtained the necessary wherewithal to launch an industrialisation process intended to render the 
country self-sufficient and certainly no longer dependent on foreign occupying colonial and military forces, British or other (Fenech 2012a, 2012b).

The same Mintoff who, in a colonial context, sought integration, a strategy conditioned by the historical and contextual specificities of the time, had worked assiduously towards self-determination tout court, brooking no half measures - no British Governor General (Patterson 2012), no NATO Europe Southern Command HQs in Malta (he immediately expelled the NATO Commander, Gino Birindelli, after winning the 1971 elections), no communication sector in British hands (as had been the case with the UK company Rediffusion), and finally no British or other military bases on the island. For this and other matters, not least that of 'standing up to Britain,' Mintoff won the admiration of many, including members of the UK working class - persons of my generation I have encountered on both sides of the Anglo-Scottish border.

He attracted international coverage for playing 'big' politics from the limits of a 'small' context but with a view one associates with persons of vision (in his case, this included a nuclear-free Mediterranean), namely that of reaching out from the local to the global and returning back to the local. His speech at Helsinki in 1975, concerning peace and security in Europe being contingent on peace in the Mediterranean, earned him accolades in the international press as did his acceptance speech for the honoris causa in Greece. He might have been despised, in certain international quarters, for being 'too big for his boots'. The Catholic Herald UK referred to him in 1985 as a 'pocket Napoleon' (Stanford 1985, 2). That most conservative of UK broadsheet papers, The Telegraph, referred to him, in an obituary (21 August 2012), as 'the irascible gadfly of Maltese politics.' I do recall however reading some edifying articles on him in the British media in the 70s, especially regarding his address to the Confederation of British Industrialists on 8 December 1977.

On the Maltese front, he was famous for his fiery oratory and his ability to feel the mass audience's pulse, adapting the tempo accordingly. He would temper his long but never dull speeches with serious affirmations, punctuated by wisecracks that would have the audience in stitches. The language could be particularly colourful and irreverent at times. For all the boisterous laughter triggered by his jokes and mimicry (reminiscent of Nyerere), nobody on the platform would be allowed to step out of line. A stern look and 
'calming down' hand gesture would be sufficient to bring everyone in tow. Journalists and anthropologists have been fascinated by his handling of large audiences at mass meetings - very much the right setting for the display of his oratorical skills. Anthropologist Jeremy Boissevain (1994) wrote an evocative account of the way Mintoff handled audiences, often serving up a master class in this regard. The House of Representatives was the other stage he helped light up, to the delight of his frontbenchers and backbenchers, sympathetic journalists, and supporters in the visitors' gallery.

Ever the populist, Mintoff was the past-master at wooing an audience. And yet he had that uncanny ability to explain some of the most complex economic and foreign policy concepts in simple but never simplistic terms. He would constantly draw on everyday examples that directly connect with people's framework of relevance.

Schooled in his politics and economics by a range of mentors including antifascist Italian socialist émigré, Umberto Calosso (who befriended the likes of Gramsci in Italy and spent time teaching in Malta), members of the Fabian society in the UK and the redoubtable Thomas Balogh at Oxford, Dom Mintoff, from the 'Tal-Bastjun' area at Bormla in the Cottonera district of Malta, was indeed larger than life. The district from which he hailed, characterised by arguably the most visible presence of the British defence forces on the island, provided the backdrop to his crowning moment of glory on the night of the 31 March 1979 as the British flag was finally lowered (signifying the closure of British bases on the island). One prominent Labour politician and minister suggested that Mintoff could have left the political scene there and then. His place on the plinth of fame, with regard to postcolonial politics, was assured.

He did not leave the scene, however, since there were more social reforms to be introduced. There followed turbulent and unsavoury times for him and his government. And yet, another honourable moment beckoned. To his colossal credit, he was to strive relentlessly to change the Constitution to ensure that the perverse electoral result of 1981 (the party with the lower number of votes in a two-horse race obtained the majority of seats) would not repeat itself. This led to his party losing the elections in 1987 through this very same amendment. A section of the Italian press at the time referred to this development as the 'suicide amendment' ('ammenda suicida'). By then Mintoff had retired from being PM and had taken a back seat. 
But a larger than life personality cannot adapt comfortably to the role of backbencher. He was to roar back by denouncing and controversially voting against his own government in 1998 ostensibly because of disagreement on a specific regional project but more likely because of his antipathy for the kind of 'New Labour' politics espoused by the government, and imposition of utility rates introduced to address the financial deficit - rates which, as he and others alleged, hit the labouring classes most. One could also easily detect elements of a personality clash involving him and the leader at the time, Prime Minster Alfred Sant. Later, having definitively retired from parliamentary politics, Mintoff campaigned vehemently, as the leading figure in the Malta Arise Front, against Malta's accession to the European Union, feeling strongly that, among other things, such an accession would undermine the country's hard-earned neutrality status (and was therefore anti-constitutional) and national sovereignty.

As expected, given his cult status, a large crowd thronged the streets and squares for his funeral cortege. His achievements were recognized even by the man who ousted his party from government in 1987 and who led the party that garnered most votes in the 1981 elections - Edward Fenech Adami (The Times, Malta, 21 August 2012). Mintoff was given the ultimate state salute worthy of a statesman and a political figure of international acclaim.

\section{References}

Austin, D (1981), Reports and Documents: The Destruction of the University of Malta. In Minerva, Vol. X1X, No.1, Spring, pp. 123-164.

Baldacchino, G (1999). Recent Developments in Higher Education in Malta. In Mediterranean Journal of Educational Studies, Vol. 4, No.1, pp. 205-214.

BBC (2012). Obituary. Dom Mintoff. Former Malta Prime Minister. In BBC News, http://www.bbc.co.uk/news/world-europe-19328193 Accessed 22/9/2012.

Boissevain, J (1994). The Politician and his audience. In R.G. Sultana and G. Baldacchino (Eds.), Maltese Society. A Sociological Inquiry. Malta: Mireva.

Borg, C and Mayo, P (2001), Social Difference, Cultural Arbitrary and Identity: an analysis of a new national curriculum document in a non-secular environment. In International Studies in Sociology of Education, Vol. 11, No. 1, pp, 63-84. 
Briguglio, M (2001). Ideological and strategic shifts from Old Labour to New Labour in Malta. Unpublished MA Sociology dissertation, Faculty of Arts, University of Malta.

Camilleri, J (2012) Il-Firma 1-Ohra (the Other Signature). In Cutajar, M (Ed.) Mintoff. Ilbniedem u l-istorja (Mintoff. The man and history), Malta: SKS.

Fenech, D (2012a). Mintoff remembered - Firebrand who forced his way to power. In The Times (Malta), 21 August.

http://www.timesofmalta.com/articles/view/20120821/local/Firebrand-forced-his-way-topower.433726 Accessed 6/9/2012

Fenech, D (2012b), Labour's Ideology and the Dilemmas of Adapting. In Chircop, J (Ed.) Revisiting Labour History, Malta: Horizons.

Livingstone, D.W. (1983). Class, Ideologies \& Educational Futures, Sussex: The Falmer Press.

Mayo, P (2012a). How Malta's Dom Mintoff Played Big Politics from a Small Context. Tribute to a Postcolonial Leader. In Counterpunch, August 31-September 02. http://www.counterpunch.org/2012/08/31/tribute-to-a-post-colonial-leader/

Mayo, P (2012b). The Worker Student Scheme 1978-1987: Consistencies and Contradictions in Labour's Socialist Politics. In J. Chircop (Ed.), Revisiting Labour History, Malta: Horizons .

Micallef, R (2012), Il-Politika Barranija ta' Dom Mintoff' (Mintoff's foreign policy). In Grech, S (Ed.) Duminku Mintoff. Bejn Storja u Miti (Dominic Mintoff. Between History and Myths), Malta: Horizons.

Mizzi, E (1995). Malta in the Making. 1962-1987. An Eyewitness Account. Malta: The Author.

MLP (1976). Lejn Malta Socjalista. 'l Quddiem fis-Sliem (Towards a Socialist Malta. Forward in Peace), Malta: Malta Labour Party.

Muscat, J (2007) Fordism, Multinationals and SMEs in the Periphery: The case of microstate Malta 1964-2004, unpublished Ph.D dissertation, University of Bristol.

Patterson, M (2012). Dom Mintoff obituary. Pivotal figure in Maltese politics who served as Labour prime minister and did battle against successive British governments. In The Guardian, 21 August. http://www.guardian.co.uk/world/2012/aug/21/dom-mintoff Accessed 22/8/2012.

Sammut, D (1989) 'Malta and the Arab World' in Society, July No 3, July pp. 16 -19 
Sant, A (2004). Is-Socjalizmu fi Zminijietna (Socialism in Our Times), Malta: SKS.

Schembri, C (1982). The Development of the Worker-Student Scheme in Malta. unpublished dissertation (B. Educ), University of Malta.

Spiteri Campbell, E (1984). The Student-Worker Scheme at the University of Malta. Department of Adult and Higher Education Occasional papers, Manchester: University of Manchester

Stanford, P (1985). From seminarian to socialist-Malta's 'pocket Napoleon.' In Catholic Herald $U K, 4^{\text {th }}$ January.

Sultana, R.G. (1992). Education and National Development. Historical and Critical perspectives on Vocational Schooling in Malta, Malta: Mireva.

Vella, M (2009). The economics of hypocrisy - deconstructing half a century of development discourse in Malta: notes on work in progress. In Cutajar, J and Cassar, G (Eds.), Social Transitions in Maltese Society, Malta: Agenda.

Vella, M (2012) Forgetting Industy. The Scarce and selective visibility of Malta's industrial experience in the field of vision of Maltese sociology. In Chircop, J (Ed.) Revisiting Labour History, Malta: Horizons.

Zammit Marmara', D (2012) Ir-Riforma tal-Edukazzjoni Sekondarja (The Reform of Secondary Education). In Cutajar, M (Ed.) Mintoff. Il-bniedem u l-istorja (Mintoff. The man and history), Malta: SKS.

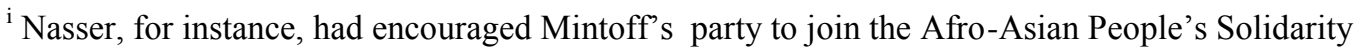
Organisation - AAPSO (Camilleri, 2012, Micallef, 2012)

${ }^{\text {ii }}$ Letter, on behalf of the Front Maltin Inqumu (Malta Arise Front), to Romano Prodi, President of the European Commission, $30^{\text {th }}$ October, 2003. I am indebted to Emmanuel Scicluna for making this and other letters by Mintoff available to me.

iii I am indebted to Mario Vella for making the exact date available and referring me to Muscat's thesis.

iv See letter by Dom Mintoff to Jose' Manuel Durão Barroso, European Commission President, 14 June 2007. Once again I thank Emmanuel Scicluna for making the letter available. Also available on http://peritmintoff.blogspot.com. Accessed $25^{\text {th }}$ November 2012.

${ }^{\mathrm{v}}$ I am indebted to Alex Sceberras Trigona who was International Secretary of the Malta Labour Party and subsequently Foreign Minister in Mintoff's time as Malta Labour Party Leader and Maltese Prime Minister. See also Dennis Sammut (1989) with regard to Mintoff's relations with the Arab world.
} 